Available online at https://jurnal.stmikroyal.ac.id/index.php/jurdimas

\title{
PELATIHAN GURU SEKOLAH DASAR DALAM PENGGUNAAN APLIKASI PERSENTASI POWTOON DAN SPARACOL
}

\author{
Achmad Fathoni*1, Ajib Rosyadi ${ }^{1}$, Indra Gunawan ${ }^{1}$, \\ Muhamad Taufik Hidayat ${ }^{1}$ \\ ${ }^{1}$ PGSD, Universitas Muhammadiyah Surakarta \\ email:*af267@ums.ac.id
}

\begin{abstract}
The purpose of this social service is to provide learning media training based on the presentation application, Sparcol and Powtoon. This activity was given to teachers in Elementary School 9 Purwodadi. The social service session consists of installing an application, creating an account, adding images and text, changing the background, and saving the results that have been made. The model used is a workshop model with lectures, demonstrations, question and answer and direct practice methods. Evaluation is done by distributing information and motivation questionnaires to participants and product checklists. In general, participants claimed that the training schedule was right, the time sharing (lectures, demonstrations, question-answer and direct practice) was also felt positively by the participants. Participants are satisfied with the topic presented and feel that most of the expectations and objectives of the social service are fulfilled. Evaluation results indicate that the material delivered can be followed well.
\end{abstract}

\section{Keyword: Powtoon Training, Sparcol Training, Elementary School}

\begin{abstract}
Abstrak: Tujuan dari pengabdian ini adalah memberikan pelatihan media pembelajaran berbasis aplikasi presentasi Sparcol dan Powtoon. Kegiatan pengabdian ini diberikan kepada guru-guru SD Negeri 9 Purwodadi. Sesi pengabdian terdiri dari instal aplikasi, membuat akun, menambah gambar dan teks, merubah background, dan menyimpan hasil yang telah dibuat. Model yang digunakan adalah model lokakarya dengan ceramah, demonstrasi, tanya jawab dan metode praktik langsung. Evaluasi dilakukan dengan menyebarkan angket informasi dan motivasi kepada peserta dan daftar periksa produk. Secara umum, peserta mengklaim bahwa jadwal pelatihan sudah tepat, pembagian waktu (ceramah, demonstrasi, tanya jawab dan praktik langsung) juga dirasakan positif oleh peserta. Peserta puas dengan topik yang disajikan dan merasa bahwa sebagian besar harapan dan tujuan pengabdian terpenuhi. Hasil evaluasi menunjukkan bahwa materi yang disampaikan dapat diikuti dengan baik.
\end{abstract}

Kata Kunci: Pelatihan Powtoon, Pelatihan Sparcol, Sekolah Dasar

\section{PENDAHULUAN}

\section{Analisis Situasi}

Di dalam proses pembelajaran, ada dua unsur yang amat penting, metode mengajar serta media pembelajaran. Kedua unsur ini juga sangat berkaitan. Pemilihan sebuah metode pembelajaran maka akan mempengaruhi jenis media pembelajaran yang sesuai. Meskipun masih ada unsur lain yang juga perlu diperhatikan seperti tujuan pembelajaran, jenis tugas, respon peserta didik serta karakteristik peserta didik. 
Available online at https://jurnal.stmikroyal.ac.id/index.php/jurdimas

Fungsi utama media pembelajaran yaitu sebagai alat bantu yang turut mempengaruhi iklim, kondisi serta lingkungan belajar yang diciptakan oleh pendidik. Pemanfaatan media pembelajaran dalam pembelajaran dapat meningkatkan minat yang baru, meningkatkan motivasi, dan juga membawa pengaruh-pengaruh psikologis terhadap peserta didik. Hal itu dikarenakan perkembangan peserta didik terdiri dari berbagai macam dimensi perkembangan seperti fisik, kognitif, intelektual, moral, sosial, emosi dan motorik (Izzaty, 2013:5).

Pemanfaatan media pembelajaran pada tahap orientasi pembelajaran akan membantu keefektifan proses pembelajaran serta penyampaian pesan pelajaran pada saat itu. Selain meningkatkan motivasi siswa, media pembelajaran juga dapat meningkatkan pemahaman, menigkatkan daya tarik, memudahkan penafsiran data dan memadatkan informasi.

Pembelajaran di Sekolah Dasar (SD) merupakan salah satu tahap pembelajaran yang penting karena akan berpengaruh pada pembelajaran jenjang selanjutnya. Pada proses belajar mengajar di SD, guru seringkali menghadapi berbagai kendala sehingga tujuan pembelajaran tidak tercapai dengan optimal. Kendala ini harus segera ditangani dengan baik, salah satunya dengan bantuan media pembelajaran. Media pembelajaran mampu memperjelas penyajian pesan sehingga dapat memperlancar proses belajar. Selain itu media pembelajaran juga mampu meningkatkan perhatian peserta didik sehingga dapat menimbulkan motivasi belajar, interaksi yang lebih langsung dengan lingkungan, serta kemungkinan peserta didik untuk belajar secara mandiri sesuai minat dan kemampuan. Media pembelajaran juga mampu mengatasi masalah keterbatasan indera, ruang, dan waktu.

Penguasaan guru SD akan teknologi informasi dan komunikasi (TIK) sangat berpengaruh sekali terhadap penguasaan guru SD dalam penggunaaan media pembelajaran. Hal ini dikarenakan media pembelajaran kontemporer banyak yang berbasis TIK.
Oleh sebab itu, kemampuan guru SD dalam menggunakan perangkat TIK sangat penting sekali. Media TIK yang dapat digunakan oleh guru dalam pembelajaran tentunya banyak sekali. Banyak media online maupun offline, software maupun hardware, dan dapat digunakan guru sebagai media pembelajaran. Menciptakan media pembelajaran berbantu teknologi menjadi salah satu keterampilan penting bagi guru SD untuk membantu siswa SD mencapai tujuan pembelajaran. Salah satu perangkat lunak yang potensial sebagai sarana penciptaan media pembelajaran yang menarik adalah Powtoon dan Sparcol. Media tersebut merupakan sebuah perangkat lunak untuk presentasi berbasis zoom in-zoom out.

SD Negeri 9 Purwodadi adalah salah satu SD Negeri yang unggulan dan mempunyai fasilitas yang lengkap dibandingkan SD Negeri lainnya, letaknya sendiri dipusat perkotaan dan berdampingan dengan Unit Pelayanan Tingkat Daerah (UPTD) Kecamatan Purwodadi. Sehingga kepala sekolah dan guru dituntut untuk bisa menjadi tenaga pendidik yang sempurna, dari tingkah laku dan cara mengajarnya.

Menurut hasil wawancara dengan kepala sekolah SD Negeri 9 Purwodadi diperoleh beberapa informasi berkaitan dengan Guru di SD Negeri 9 Purwodadi, yaitu sebagai berikut: (1) Laptop hanya digunakan untuk membuat tugas individual guru, tidak digunakan untuk penunjang proses pembelajaran. (2) SD Negeri 9 Purwodadi mempunyai layar proyektor, tetapi layar proyektor tersebut digunakan hanya untuk rapat sekolah, Kelompok Kerja Guru (KKG) dan juga acara lainnya yang keluar dari proses pembelajaran. (3) Guru SD Negeri 9 Purwodadi dalam proses pembelajaran hanya mengandalkan atau menggunakan buku dan juga hal disekeliling sekolah, sehingga inovasi untuk menumbuhkan minat belajar masih terlihat sempit atau sedikit. (4) Guru SD Negeri 9 Purwodadi belum menguasai inovasi aplikasi-aplikasi presentasi yang terdapat didalam laptop dan komputer, penguasaannya hanya sebatas Power Point saja. 
Available online at https://jurnal.stmikroyal.ac.id/index.php/jurdimas

Berdasarkan paparan di atas jelas bahwa akar permasalahan belum optimalnya kinerja guru SD Negeri 9 Purwodadi dalam inovasi pembelajaran. Dikarenakan belum adanya sistem pembinaan atau pelatihan tentang inovasi aplikasi-aplikasi presentasi kepada guru-guru SD Negeri 9 Purwodadi. Sehingga dari masalah diatas pengabdian ini mempunyai fokus untuk melatih inovasi aplikasi presentasi dengan menggunakan aplikasi Sparcool dan Powtoon.

\section{Identifikasi Dan Perumusan Masalah}

Dari analisis situasi di atas dapat mengambil kesimpulan permasalahan yang dihadapi oleh Guru di SD Negeri 9 Purwodai yaitu tidak mempunyai inovasi-inovasi dalam mengembangkan proses pembelajaran kearah penggunaan teknologi yang dipunyai oleh guru dan sekolah, kemudian tidak mempunyai inovasi-inovasi dalam presentasi selain aplikasi Power Point. Dari latar belakang di atas, maka rumusan permasalahan yang dapat ditarik adalah bagaimana konsep pelatihan aplikasi presentasi Sparcol dan Powtoon kepada guru SD Negeri 9 Purwodadi, Kecamatan Purwodadi, Kabupaten Grobogan?

\section{Tujuan Kegiatan}

Adapun tujuan yang ingin dicapai melalui kegiatan pengabdian ini adalah memberikan pelatihan aplikasi presentasi Sparcool dan Powtoon kepada guru SD Negeri 9 Purwodadi, Kecamatan Purwodadi, Kabupaten Grobogan.

\section{Manfaat Kegiatan}

Hasil kegiatan pengabdian pada masyarakat ini akan memberikan kontribusi positif terhadap usaha peningkatan kualitas kinerja guru. Secara eksplisit kontribusi hasil kegiatan pengabdian masyarakat ini dapat dijabarkan sebagai berikut.

1. Bagi SD, program ini membantu SD dalam optimalisasi sumber daya sekolah.

2. Bagi guru SD,program ini membantu guru mengembangkan keterampilan mereka dalam menciptakan media pembelajaran berbasis TIK yang atraktif. Selain itu, program ini juga dapat membantu guru SD mengatasi masalah belajar siswa SD dengan berbantu media pembelajaran.

\section{METODE}

\section{Tahap Persiapan}

Tujuan dari program pelatihan Powtoon dan Sparcol ini adalah untuk membuat guru melek terhadap IPTEK dan pengembangan media pembelajaran Prezi, Powtoon dan Sparcol.

Adapun rincian rencana pelaksanaan sosialisasi program pelatihan ini sebagai berikut:

Waktu : Sabtu, 16 Maret 2019

Tempat: Ruang Kelas SD Negeri 9 Purwodadi.

Peserta : Guru SD Negeri 9 Purwodadi

Materi : Media Pembelajaran Powtoon, dan Sparcol

Alat-alat yang dibutuhkan antara lain:
a. Laptop
b. Alat tulis
c. Liquid Crystal Display (LCD)
d. Wifi/Koneksi Internet
e. Microphone
f. Kamera
g. Flashdisk

Bahan-bahan yang dibutuhkan yaitu Aplikasi Powtoon dan Sparcol.

\section{Tahap Pelaksanaan}

Persiapan alat dan bahan selama pelatihan Powtoon dan Sparcol berlangsung, perlu dipersiapkan alat dan bahan. Alat yang digunakan adalah buku panduan/modul, alat tulis, laptop, liquid crystal display (LCD), koneksi Internet, kamera dan microphone.

\section{Pelatihan Powtoon dan Sparcol untuk Guru SD}

Pelatihan ini terbagi dalam sekali pertemuan dalam ruangan dan tiap pertemuan mempunyai topik yang berbeda serta seminggu pertemuan lapangan. Tema 
Available online at https://jurnal.stmikroyal.ac.id/index.php/jurdimas

dalam tiap pertemuan tertera dalam tabel berikut ini.

Tabel 1 Pelaksanaan Pelatihan Powtoon dan Sparcol

\begin{tabular}{ll}
\hline Hari & \multicolumn{1}{c}{ Materi } \\
\hline I & a. Pembukaan \\
& b. Pengenalan media pembelajaran \\
& menggunakan Powtoon. \\
& c. Melatih membuat akun Powtoon \\
& d. Menampilkan contoh media \\
& pembelajaran Powtoon. \\
& e. Membimbing pembuatan Media \\
& Pembelajaran menggunakan \\
& Powtoon. \\
II & a. Pengenalan media pembelajaran \\
& menggunakan Sparcol. \\
& b. Membimbing penginstalan aplikasi \\
& Sparcol \\
& c. Membimbing pembuatan Media \\
& Pembelajaran menggunakan \\
& Sparcol. \\
\hline &
\end{tabular}

\section{Evaluasi Pelaksanaan Program}

Pada sesi ini dilakukan tanya jawab atau diskusi mengenai permasalahanpermasalahan yang dijumpai di lapangan. Setelah itu untuk mengetahui keberhasilan pelaksanaan kegiatan ini, dilakukan evaluasi di akhir pelaksanaan kegiatan, Untuk mengukur keberhasilan kegiatan pengabdian maka diadakan evaluasi. Evaluasi dilakukan dengan cara menyebarkan angket pengetahuan dan motivasi pada peserta, serta penilaian produk. Instrumen yang digunakan adalah angket pengetahuan dan motivasi serta daftar cek produk.

\section{PEMBAHASAN}

\section{Pembukaan dari Kepala Sekolah}

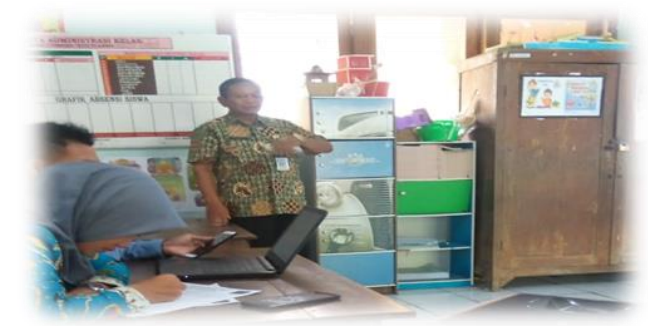

Gambar 1. Kata Sambutan Kepala Sekolah
Kepala Sekolah SD Negeri 9 Purwodadi memberikan sambutan dalam kegiatan tersebut, Kepala Sekolah sangat antusias sekali karena pelatihan tersebut dianggap penting, dan sangat dibutuhkan kepada guru-guru di SD Negeri 9 Purwodadi tersebut. Media berbasis aplikasi Sparkol dan Powtoon dianggap sebagai media yang sangat membatu dalam proses pembelajaran khususnya dalam penerapan PAIKEM. Bapak Kepala Sekolah sangat berharap program pelatihan ini bisa dilaksanakan lebih banyak lagi.

\section{Pengenalan Media Pembelajaran Menggunakan Sparkol dan Powtoon}

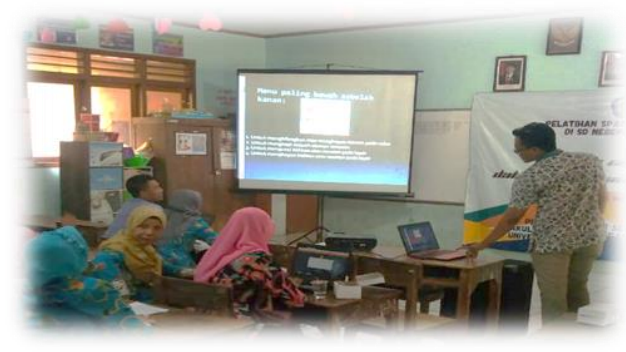

Gambar 2. Perkenalan Media Pembelajaran

Pengenalan media pembelajaran menggunakan sparkol dan powtoon yang didalamnya telah diberikan penjelaskan secara singkat tentang media sparkol dan powtoon, dalam kegiatan tersebut peserta sangat antusias dan penasaran tentang aplikasi sparkol dan powtoon sehingga timbul pertanyaan dari peserta sebagai berikut cara kerja dari aplikasi sparkol dan powtoon itu nanti seperti apa ?, dan cara buatnya susah atau tidak? Sehingga rasa penasaran tersebut diberikan penguatan secara perlahan bahwa aplikasi sparkol dan powtoon itu sangat mudah.

\section{Melatih Membuat Akun Powtoon}

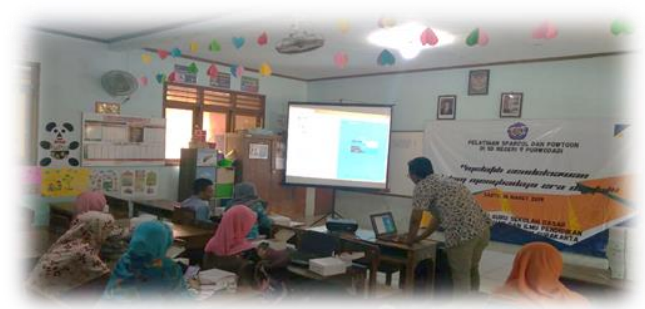

Gambar 3. Pembuatan Akun 
Available online at https://jurnal.stmikroyal.ac.id/index.php/jurdimas

Kegiatan pada sesi ini diberikan tata cara dalam membuat akun untuk mengoprasikan aplikasi Powtoon. Adapun cara dalam membuat akun powtoon sebagai berikut:

Pertama kali buka websitenya di alamat https://www.powtoon.com/ kemudian klik tombol warna biru yang ada tulisan START NOW, dalam langkah tersebut peserta dapat mengikuti tanpa ada halangan suatu apapun. Setelah mengunjungi website Powtoon tersebut, kemudian muncul halaman pendaftaran. Jika belum mendaftar menjadi anggota di web Powtoon, silahkan mendaftar terlebih dahulu. Daftarnya bisa menggunakan akun Google, Facebook, Linkedin, atau E-mail.

Langkah kedua ini terdapat halangan dari beberapa peserta dari tidak mempunyai akun Google, akun Facebook, akun Linekedin dan akun E-mail. Halangan tersebut bisa dilalui dengan menggunakan akun Google, Facebook, dan akun E-mail dari orang terdekat misalnya suami, istri dan anak.

Kemudian langkah keempat ialah jika sudah memiliki akun, klik tulisan Log in. Isi username dan passwordnya bila menggunakan email atau menggunakan akun Google, Facebook, maupun Linkedin, dalam langkah ke empat ini tida terdapat halangan karena halangan sudah terselesaikan pada langkah ketiga. Ke emapat langkah tersebut sudah dilaksanakan tanpa halangan suatu apapun dalam sesi pendaftaran akun Powtoon.

\section{Melatih Mengoperasikan Aplikasi Powtoon}

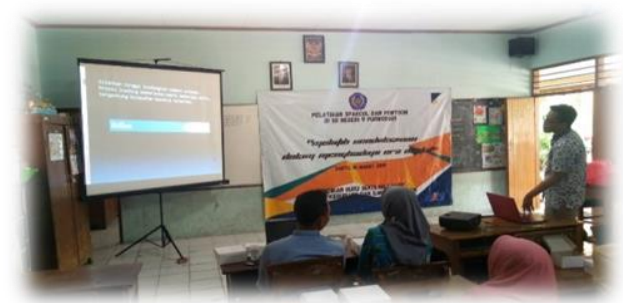

Gambar 4. Materi Mengoprasika Aplikasi Powtoon
Kegiatan pada sesi ini yaitu memberikan ilmu-ilmu dasar dalam mengoperasikan aplikasi Powtoon serta langkah-langkah yang dilakukan setelah mendaftar akun Powtoon sebagai berikut:

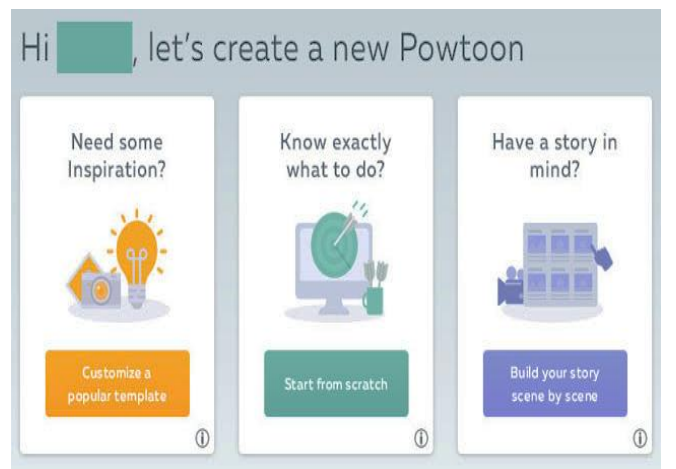

Gambar 5. Tampilan Menu Aplikasi

Setelah Log in akan tampil menu untuk membuat animasi. Dalam tutorial ini saya memilih Build your story scene by scene. Kemudian tampil menu untuk membuat tampilan dari animasi yang akan dibuat. Terdiri dari berbagai macam pilihan, yaitu professional, white board, infographic, cartoon, dan CORPORATE. Dalam tutorial ini saya memilih CARTOON. Tidak lama kemudian tampil menu Your storyboard structure. Silahkan pilih sesuai dengan keinginan atau langsung saja klik tombol warna biru yang ada tulisan CONTINUE.

Kemudian pemberi materi memaparkan panel dan fungsi-fungsinya sebagai berikut:

Panel yang ada di sebelah kanan memiliki fungsi untuk mengatur Layouts, Background, Text, Library, Objects, Graphs, Sound, dan Images yang akan dimasukkan ke dalam Panel Timeline.

Kemudian langkah-langkah dalam menyimpan sebagai berikut:

Apabila telah selesai membuat animasi sesuai dengan kebutuhan, klik tombol Export. Kemudian tampil menu EXPORT OPTIONS. Silahkan pilih fitur yang akan digunakan, misalnya kita pilih Download as MP4 atau Upload to YouTube. 
Available online at https://jurnal.stmikroyal.ac.id/index.php/jurdimas

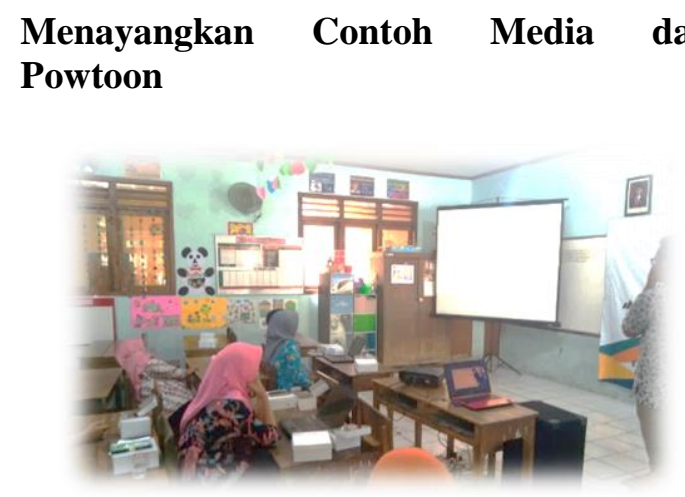

Gambar 6. Pemberian Materi

Pada sesi ini pemberi materi menayangkan contoh media dari aplikasi powtoon yang sudah disiapkan oleh pemberi materi, kemudian setelah menayangkan contoh media dari powtoon guru diminta untuk membuat sendiri media yang sederhana berasal dari aplikasi powtoon.

\section{Membimbing Penginstalan Aplikasi Sparcol}

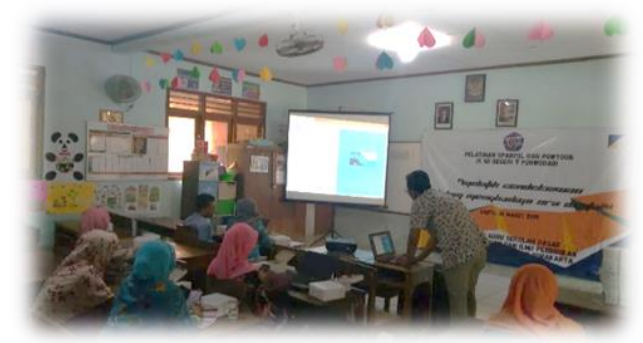

Gambar 7. Pengistalan Aplikasi Powtoon

Pada tahap membimbing pengintalan aplikasi ini pemberi materi memaparkan langkah-langkah dalam penginstalan, mulai dari memindahkan aplikasi ke setiap laptop sampai dengan membuat aplikasi dari online menjadi offline. Pada tahap ini guru sedikit sulit untuk mengikuti sehingga pada tahap penginstalan masih banyak bantuan dari pemberi materi yang lainnya.

\section{Membimbing Pembuatan Media Dari Aplikasi Sparcol}

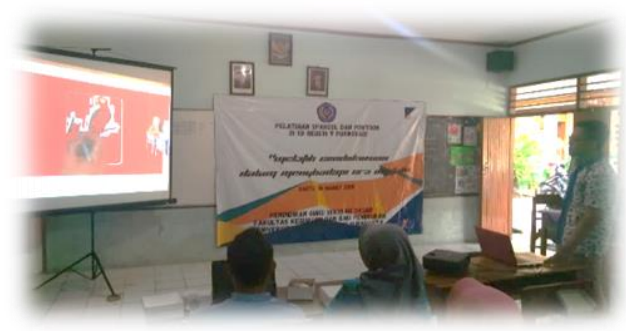

Gambar 8. Hasil Tampilan Aplikasi Powtoon

Pada tahap ini pemberi materi membimbing guru langkah-langkah sederhana dalam pengoperasian aplikasi sparcol dari cara menambahkan gambar, cara mengatur cepat lambat tampilan, dan cara menampilkan. Setelah dibimbing dalam pengoperasian aplikasi sparcol, kemudian guru diminta untuk membuat sendiri media yang sederhana dengan menggunakan aplikasi sparcol.

\section{DAFTAR PUSTAKA}

Anitah, Sri. 2012. Media Pembelajaran.Surakarta: Yuma Pustaka.

Azhar, Arsyad.2013. Media Pembelajaran. Jakarta: Rajawali Pers.

Izzaty R.E., dkk. 2013. Perkembangan Peserta Didik. Yogyakarta. UNY Press.

Prastowo, A. 2011. Panduan Kreatif Membuat Bahan Ajar Inovatif. Yogyakarta: Penerbit DIVA (Anggota IKAPI).

Rusman., Deni Kurniawan., Cepi Riyana. 2011. Pembelajaran Berbasis Teknologi Informasi dan Komunikasi. Jakarta: PT. Rajagrafindo Persada.

Sadiman, dkk. 2011. Media Pendidikan, Pengertian, Pengembangan, dan Pemanfaatannya. Jakarta: PT. Raja Grafindo Persada. 